\title{
Pengaruh Store Image Toko Ikan Hias Terhadap Keputusan Pembelian Konsumen
}

\author{
Indah Handaruwati \\ Fakultas Ekonomi Universitas Kristen Surakarta \\ Jln.R.Wolter Monginsidi 36-38 Surakarta \\ indahhandaruwati80@gmail.com
}

\begin{abstract}
This study aims to analyze the effect of the store image of an ornamental fish shop which consists of merchandise variables, shop location, employee services, and prices on consumer purchasing decisions. The sample in this study were 105 respondents who were willing and willing to take the time to fill out a questionnaire that was taken using purposive and convience sampling methods. Data collection using a questionnaire. Data analysis was performed by multiple linear regression with SPSS 17.00 software. The results of this study indicate that merchandise has an effect on consumer purchasing decisions with a significance value of 0.002 , while the $t$ table is 3.260, so the value of $t$ count is greater than the $t$ table. Store location does not have a significant effect on purchasing decisions at the Bintang Aquarium Solo Shop, as evidenced by a significance value of 0.551 while $t$ count 0.598 , the $t$ value is smaller than the $t$ table value. Employee service is not significant towards consumer purchasing decisions at Bintang Aquarium Solo Shop, as evidenced by the $t$ value of 1.450 while the significance value is 0.150 , so the value of $t$ count is smaller than $t$ table. Price affects consumer purchasing decisions at the Bintang Aquarium Solo shop, as evidenced by the $t$ value of 2,400, while the significance value is 0.018 , so the value of $t$ is greater than the value of $t$ table.
\end{abstract}

Keywords: Store Image, Merchandise, Store Location, Employee Service, Price, Purchase Decision

\begin{abstract}
Abstrak- Penelitian ini bertujuan untuk menganalisis pengaruh store image toko ikan hias yang terdiri dari varibel barang dagangan, lokasi toko, pelayanan pegawai, dan harga terhadap keputusan pembelian konsumen. Sampel dalam penelitian ini adalah 105 responden yang bersedia dan mau meluangkan waktunya untuk pengisian kuesioner yang diambil menggunakan metode purposive dan convience sampling. Pengumpulan data menggunakan kuisoner. Analisis data dilakukan dengan uji regresi linear berganda dengan software SPSS 17.00. Hasil penelitian ini menunjukan bahwa barang dagangan berpengaruh terhadap keputusan pembelian beli konsumen dengan nilai signifikansi sebesar 0,002 sedangkan t table 3,260 maka nilai nilai t hitung lebih besar nilai t tabel. Lokasi toko tidak berpengaruh signifikan terhadap keputusan pembelian di Toko Bintang Aquarium Solo, dibuktikan dengan nilai signifikansi sebesar 0,551 sedangkan $t$ hitung 0,598 maka nilai $t$ hitung lebih kecil dari nilai $t$ tabel. Pelayanan pegawai tidak signifikan terhadap keputusan pembelian konsumen di Toko Bintang Aquarium Solo, dibuktikan dengan nilai t hitung 1,450 sedangkan nilai signifikansi 0,150 maka nilai $t$ hitung lebih kecil dari $t$ tabel. Harga berpengaruh terhadap keputusan pembelian konsumen di Toko Bintang Aquarium Solo, dibuktikan dengan nilai $t$ hitung 2,400 sedangkan nilai signifikansi 0,018 maka nilai $t$ hitung lebih besar dari nilai $t$ tabel.
\end{abstract}

Kata Kunci : Store Image , Barang Dagangan, Lokasi Toko, Pelayanan Pegawai, Harga, Keputusan Pembelian

\section{PENDAHULUAN}

Indonesia pada tahun 2015 menduduki posisi ketiga sebagai Negara pengekspor ikan hias terbesar didunia. Dengan nilai mencapai sekitar 5,43 juta US\$ untuk ikan hias air laut dan 14,16 juta US\$ untuk ikan hias air tawar. Kurang lebih ada 1.300 spesies ikan hias air tawar dan 650 spesies ikan hias air laut yang bisa dikembangkan di jadikan ladang usaha potensial. Usaha ikan hias merupakan salah satu bisnis yang memiliki prospek cukup menjanjikan secara ekonomi. Setiap tahunnya peminat pasar dari bisnis ini terus mengalami peningkatan, dibuktikan dengan menjamurnya komunitas pecinta ikan hias di berbagai kota.

Persaingan usaha ikan hias dikota Surakarta cukup ramai antara lain Dunia Ikan Hias, Permai
Aquarium, Solo Koi, Grace Aquahouse, Bintang Aquarium Solo, dan lain sebagainya Meningkatnya pemilik usaha yang terjun pada bisnis ikan hias tidak lepas dari banyaknya tuntutan konsumen untuk memenuhi kebutuhannya sehingga persaingan yang terjadi makin ketat yang pada akhirnya toko yang memiliki image yang baik akan mampu mempengaruhi keputusan pembelian konsumen.

Store Image adalah kepribadian toko yang melekat pada konsumen seperti produk sebuah toko juga mempunyai kepribadian. Store Image menggambarkan apa yang dilihat dan dirasakan konsumen terhadap toko tertentu. Store Image memiliki peran yang penting bagi sebuah toko.Store Image bukan hanya menjadi persepsi bagi konsumen sehingga selalu menjadi tempat berbelanja namun juga 
memiliki banyak manfaat bagi toko termasuk menjadi kekuatan dalam pengembangan strategi bersaing.

Penelitian Maharta dkk (2017) menyimpulkan bahwa Store Image memiliki pengaruh signifikan terhadap keputusan pembelian. Variabel store image dalam penelitian ini yaitu fasilitas fisik, barang dagangan, kenyamanan, dan pelayanan berpengaruh baik secara parsial maupun simultan terhadap keputusan pembelian semakin baik Store Image maka semakin tinggi keputusan seseorang untuk membeli. Penelitian Nur Yudiono dkk ( 2016 ) dengan variabel penelitian yaitu Pelayanan Pegawai, Kualitas Produk, Ragam Produk, Suasana Toko, Kenyamanan dan Harga. Hasil penelitian ini yaitu variable pelayanan pegawai, ragam produk dan harga berpengaruh secara signifikan.Sedangkan variabel kualitas produk dan suasana toko tidak memiliki pengaruh yang signifikan dalam menciptakan Citra Toko. Penelitian Tommy Subagyo dan Hartono Subagio ( 2014 ) memberikan kesimpulan bahwa variable promotion memiliki pengaruh paling dominan diantara variable physical facilities, merchandise, price, dan promotion service.

Kepribadian atau image merupakan kepribadian toko yang melekat di benak konsumen terhadap sebuah toko, kepribadian atau image toko menggambarkan apa yang dilihat dan dirasakan oleh konsumen terhadap toko tertentu. Menciptakan sebuah image yang baik bagi konsumen adalah pekerjaan yang tidak mudah, image adalah suatu bayangan atau gambaran yang ada didalam benak seorang yang timbul karena emosi atau reaksi terhadap lingkungan sekitarnya.( Sopian\& Syihabuddin, $2008: 138$ ) .

\section{Pengertian Store Image}

\section{KAJIAN PUSTAKA}

Loudon dan Bitta (1993) berpendapat, "Store image is a complex of tangible or functional factors and intangible or psychological factors that a consumer perceives to be present in a store". Store Image merupakan gabungan antara faktor fisik misalnya tata letak barang, kebersihan ruangan, dan lain-lain dengan faktor non fisik misalnya kecepatan layanan terhadap keluhan, keramahan karyawan, ketelitian kasir yang kesemuanya itu dapat diterima dan dirasakan akibat dan manfaatnya sebagai kesan konsumen dari suatu toko. Kotler (2007:172) mendefinisikan store image sebagai "seperangkat keyakinan, ide dan kesan yang dimiliki oleh seseorang terhadap suatu objek". Selanjutnya Kotler (2007:173) menyatakan store image merupakan "sikap dan tindakan seseorang terhadap suatu objek sangat dikondisikan citra dari objek tersebut".

\section{Pengertian Barang Dagangan}

Merchandising atau pengelolaan barang dagangan adalah proses penanganan kreatif dalam upaya mempresentasikan atau menampilkan produk (barang dagangan) dengan tujuan memaksimalkan daya tarik penjualan ritel (Utami 2008:28). Menurut Kotler dalam Foster (2008:61) suasana (atmosfer) setiap toko mempunyai tata letak fisik yang memudahkan atau menyulitakan untuk berputarputardidalamnya.Setiap toko mempunyai penampilan yang berbeda-beda baik itu kotor, menarik, megah, dan suram. Suatu toko harus membentuk suasana terencana yang sesuai dengan pasar sasarannya dan dapat menarik konsumen untuk membeli di toko tersebut.

\section{Pengertian Lokasi Toko}

Lokasi adalah tempat dimana sesuatu berada. Lokasi merupakan keputusan yang dibuat perusahaan berkaitan dengan dimana operasi dan stafnya akan ditempatkan. Salah memilih lokasi perusahaan mengakibatkan kerugian bagi perusahaan. Lokasi merupakan gabungan antara lokasi dan keputusan atas saluran distribusi, dalam hal ini berhubungan dengan cara penyampaian jasa kepada konsumen dan dimana lokasi yang strategis (Lupiyoadi, 2001).

MenurutMursyid (2008) lokasi adalah suatu penjelasan teoretis yang dikaitkan dengan tata ruang dari kegiatan. Kategori tempat yang digunakan dalam penelitian ini adalah berupa minimarket yang berada di kota Semarang, Dilihat dari sisi lokasi minimarket ini cukup strategis. Keterjangkauan lokasi bagi masyarakat, lahan parkir yang cukup luas, dan tata ruang yang tidak sempit. Oleh karena itu, indikator variabel penelitian untuk kategori lokasi minimarket berupa lokasi mudah diakses, serta segala desain dan fasilitas yang dimilikinya dapat memenuhi kebutuhan konsumen. Dengan demikian maka diharapkan konsumen akan lebih merasa nyaman dengan tempat yang disediakan dan bukan merupakan hambatan yang disebabkan oleh tempat.

\section{Pengertian Pelayanan Pegawai}

Menurut Kotler (2007) Pelayanan (service) dapat di definisikan sebagai suatu tindakan atau kinrja yang diberikan seseorang kepada orang lain. Pelayanan dapat diklasifikasikan menjadi dua yaitu High Contact Service adalah klasifikasi pelayanan jasa dimana kontak antara konsumen dan penyedia jasa yang sangat tinggi, konsumen selalu terlibat dalam proses dari layanan jasa tersebut. Low Contact Service adalah klasifikasi pelayanan jasa dimana kontak antara 
konsumen dengan penyedia jasa tidak terlalu tinggi. Physical contact dengan konsumen hanya terjadi di front desk.

\section{Pengertian Harga}

Harga menurut Kotler dan Amstrong (2001) adalah sejumlah uang yang ditukarkan untuk sebuah produk atau jasa.Namun harga juga dapat menjadi indikator kualitas dimana suatu produk dengan kualitas tinggi akan berani dipatok dengan harga yang tinggi pula. Harga dapat mempengaruhi konsumen dalam mengambil keputusan untuk melakukan pembelian suatu produk.

\section{Pengertian Keputusan Pembelian}

Keputusan Pembelian menurut Philip Kotler (2007:223) yaitu : "beberapa tahapan yang dilakukan oleh konsumen sebelum melakukan keputusan pembelian suatu produk". Sedangkan Menurut Chapman dan Wahlers (1999, p. 176) Keputusan Pembelian adalah : "sebagai keinginan konsumen untuk membeli suatu produk. Konsumen akan memutuskan produk yang akan dibeli berdasarkan persepsi mereka terhadap produk tersebut berkaitan dengan kemampuan produk tersebut dalam memenuhi kebutuhannya".

\section{Pengembangan Hipotesis}

Pengaruh Barang Dagangan Terhadap Keputusan Pembelian

Merchandising atau pengelolaan barang dagangan adalah proses penanganan kreatif dalam upaya mempresentasikan atau menampilkan produk (barang dagangan) dengan tujuan memaksimalkan daya tarik penjualan ritel (Utami 2008:28). Hal ini didukung oleh penelitian Gede Wahyu Maharta, Made Ary Meitriana, dan Anjuman Zukhri (2017) bahwa barang dagangan berpengaruh secara signifikan pada keputusan pembelian.Oleh karena itu hipotesis dirumuskan sebagai berikut :

H1 : Diduga adanya pengaruh barang dagangan terhadap keputusan pembelian konsumen di Toko Bintang Aquarium.

\section{Pengaruh Lokasi Toko Terhadap Keputusan Pembelian}

Lokasi adalah tempat dimana sesuatu berada. Lokasi merupakan keputusan yang dibuat perusahaan berkaitan dengan dimana operasi dan stafnya akan ditempatkan. Salah memilih lokasi perusahaan mengakibatkan kerugian bagi perusahaan. Lokasi merupakan gabungan antara lokasi dan keputusan atas saluran distribusi, dalam hal ini berhubungan dengan cara penyampaian jasa kepada konsumen dan dimana lokasi yang strategis (Lupiyoadi, 2001).Hal ini didukung oleh penelitian Christian Hadi Wijaya (2013) bahwa lokasi toko berpengaruh secara signifikan pada keputusan pembelian. Oleh karena itu hipotesis dirumuskan sebagai berikut :

H2 : Diduga adanya pengaruh lokasi toko terhadap keputusan pembelian konsumen di Toko Bintang Aquarium.

\section{Pengaruh Pelayanan Pegawai Terhadap Keputusan Pembelian}

Kotler dalam Rambat Lupiyoadi (2013:228) berpendapat bahwa kepuasan merupakan tingkat perasaan di mana seseorang menyatakan hasil perbandingan atas kinerja produk jasa yang diterima dengan yang diharapkan, pencapaian kepuasan pelanggan melalui kualitas pelayanan dapat ditingkatkan dengan beberapa pendekatan berikut ini (Kotler dalam Rambat Lupiyoadi (2013:228).Hal ini didukung oleh penelitian Gede Wahyu Maharta, Made Ary Meitriana, dan Anjuman Zukhri (2017) bahwa pelayanan pegawai berpengaruh secara signifikan pada keputusan pembelian. Oleh karena itu hipotesis dirumuskan sebagai berikut :

H3 : Diduga adanya pengaruh Pelayanan Pegawai terhadap keputusan pembelian konsumen di Toko Bintang Aquarium.

Pengaruh Harga Terhadap Keputusan Pembelian Harga menurut Kotler dan Amstrong (2001) adalah sejumlah uang yang ditukarkan untuk sebuah produk atau jasa.Namun harga juga dapat menjadi indikator kualitas dimana suatu produk dengan kualitas tinggi akan berani dipatok dengan harga yang tinggi pula. Harga dapat mempengaruhi konsumen dalam mengambil keputusan untuk melakukan pembelian suatu produk.Hal ini didukung oleh penelitian Tommy Soebagyo dan Dr Hartono Subagio M.M.(2014) bahwa harga berpengaruh secara signifikan pada keputusan pembelian.Oleh karena itu hipotesis dirumuskan sebagai berikut :

H4 : Diduga adanya pengaruh Harga terhadap keputusan pembelian konsumen di Toko Bintang Aquarium

Pengaruh Barang Dagangan, Lokasi Toko, Pelayanan Pegawai, dan Harga Terhadap Keputusan Pembelian

Penelitian ini mengembangkan hipotesis dari penelitian sebelumnya secara simultan.

H5: Diduga adanya pengaruh Barang Dagangan, Lokasi Toko, Pelayanan Pegawai, Harga terhadap keputusan pembelian konsumen di Toko Bintang Aquarium 


\section{METODE PENELITIAN \\ Ruang Lingkup \\ Obyek penelitian ini adalah Toko Bintang \\ Aquarium Solo yang berada di kota Surakarta.}

\section{Sumber Data}

Adapun sumber data yang digunakan dalam penelitian ini adalah :

1) Data Primer, yakni data mengenai pendapat responden, melalui kuisoner.

2) Data Sekunder, yakni data yang diperoleh secara tidak langsung melalui perantara (diperoleh dan dicatat oleh pihak lain kemudian dipublikasikan) contohnya internet dan buku-buku teks yang menjadi acuan teoritis dalam penelitian ini.

\section{Populasi dan Sampel}

Populasi adalah sekelompok orang, benda, atau hal yang menjadi sumber pengambilan sampel; suatu kumpulan yang memenuhi syarat tertentu yang berkaitan dengan masalah penelitian.Populasi dalam penelitian ini adalah konsumen Toko Bintang Aquarium Solo adalah bagian dari jumlah dan karakteristik yang dimiliki populasi.Sampel dalam penelitian ini adalah beberapa responden yang diambil menggunakan metode purposive sampling. Metode ini menggunakan Kriteria responden dalam penelitian ini konsumen yang telah membeli produk di Toko Bintang Aquarium Solo. Sampel yang didapat berjumlah 100 responden, sebelumnya peneliti menyebar kuisoner sejumlah 105 kuisoner, yang kembali 103, dan yang dianalisis 100 kuisoner, sisanya tidak digunakan.

\section{Teknik Pengumpulan Data}

Metode pengumpulan data yang digunakan dalam penelitian ini adalah metode survei, dengan teknik pengumpulan datanya dengan kuisoner. Kuisoner adalah salah satu teknik pengumpulan data melalui formulir-formulir yang berisi pertanyaan yang disampaikan secara tertulis pada responden untuk mendapatkan jawaban atau tanggapan sebagi data penelitian dengan kriteria-kriteria tertentu. Data diambil dari responden dengan menggunakan kuesioner (angket). Responden menilai setiap pertanyaan dengan menggunakan skala Likert 5 poin. "Skala Likert digunakan untuk mengukur sikap, pendapat, dan persepsi seseorang atau sekelompok orang tentang fenomenasosial" (Sugiyono, 2011:93).Skala Likert dalam penelitian ini terdiri atas lima skala, dimana masing-masing penilaiannya sebagai berikut :

1 = Sangat tidak setuju (STS)

$2=$ Tidak setuju (TS)

$$
\begin{aligned}
& 3=\operatorname{Netral}(\mathrm{N}) \\
& 4=\text { Setuju }(\mathrm{S}) \\
& 5=\text { Sangat setuju (SS) }
\end{aligned}
$$

\section{Definisi Operasional Variabel}

Variabel yang digunakan dalam penelitian ini terdiri dari variabel independen dan variabel dependen.

a. Variabel Independen

Variabel independen (X) adalah variabel yang menjelaskan atau mempengaruhi variabel yang lain. Variabel independen dalam penelitian ini terdiri atas Barang Dagangan (X1), Lokasi Toko (X2), Pelayanan Pegawai (X3), dan Harga (X4).

b. Variabel Dependen

Variabel dependent adalah suatu variabel yang variasi nilainya dipengaruhi atau dijelaskan oleh variasi nilai variabel yang lain (Mustafa, 2009). Variabel dependen dalam penelitian ini adalah keputusan pembelian.

Pengukuran variabel dependen

\section{Teknik Analisis Data \\ Pengujian Kualitas Data \\ Uji Validitas}

Uji validitas digunakan untuk mengukur sah atau tidaknya suatu alat ukur, dalam hal ini kuesioner. Suatu kuesioner dikatakan valid jika pertanyaan atau pernyataan dalam kuesioner tersebut megungkapkan sesuatu yang akan diukur oleh kuesioner tersebut (Sugiyono, 2015). Uji validitas dilakukan dengan menghitung korelasi antar skor total. Jika koefisien korelasinya positif, maka indikator yang bersangkutan dianggap valid (validitas kriteria). Pengujian validitas menggunakan Ms. Excel.Kriteria item pernyataan dinyatakan valid jika r-hitung $>$ r-tabel.

\section{Uji Reliabilitas}

Uji realibilitas menunjukkan sejauh mana suatu alat ukur dapat diandalkan atau dipercaya untuk mengukur suatu objek yang akan diukur, dan untuk melihat konsistensi alat ukur dalam mengukur gejala yang sama (Sugiyono, 2015). Semakin besar nilai a (alpha), maka semakin besar pula reliabilitasnya. Pengujian reliabilitas terhadap semua item atau pernyataan yang dipergunakan pada penelitian ini akan menggunakan kriteria Cronbach Alpha (koefisien Alpha Cronbach), yang ssecara umum dianggap reliabel apabila nilai alfa Cronbachnya $>0.6$.

Uji Asumsi Klasik

\section{Uji Normalitas}

Menurut Widodo (2017:80) uji normalitas digunakan untuk menguji apakah variabel pengganggu atau 
residual dalam model regresi memiliki distribusi normal atau tidak.Model regresi yang baik adalah distribusi data normal atau mendektai normal, pengujian ini menggunakan uji Kolmogorov Smirnov. Distribusi dikatakan normal apabila nilai signifikan hitung $>0,05$.

\section{Uji Multikolinieritas}

Uji Multikoliniearitas menurut Sugiyono (2015 : 331) merupakan salah satu asumsi yang digunakan dalam analisis regresi, uji multikoliniearitas bertujuan untuk menguji apakah di dalam model regresi terdapat korelasi antara variabel bebas. Model regresi yang baik seharusnya tidak terjadi korelasi di antara variabel bebas. Sugiyono (2015 : 332 ) menyatakan bahwa dalam mendeteksi ada atau tidaknya multikoleniearitas dapat dilihat dari tolerance valuedan variance inflation factor (VIF), batas tolerance value $>0,10$ danvariance inflation factor (VIF) adalah $<10$ maka terjadi tidak terjadi multikoleniearitas, sebaliknya tolerance value < 0,10danvariance inflation factor (VIF) $>10$ maka terjadi multikoleniearitas.

\section{Uji Heteroskedastisitas}

Menurut Sugiyono (2015:336) uji heteroskedastisitas digunakan untuk mengetahui variabel pengganggu dalam persamaan regresi mempunyai varians yang sama atau tidak. Apabila nilai signifikansi lebih besar dari 0,05 , maka tidak terdapat gejala heteroskedastisitas. Dalam model regresi yang baik seharusnya tidak terjadi heteroskedastisitas. Untuk menguji ada tidaknya heteroskedastisitas dalam penelitian ini digunakan analisis pada gambar scatterplot yang menyatakan model regresi linear berganda tidak terdapat heroskedastisitas jika:

1) Titik-titik data menyebar di atas dan di bawah atau di sekitar angka 0 .

2) Titik-titik data tidak mengumpul hanya di atas atau di bawah saja.

3) Penyebaran titik-titik data tidak boleh membentuk pola bergelombang melebar kemudian menyempit dan melebar kembali.

\section{Uji Validitas}

\section{HASIL DAN PEMBAHASAN}

Variabel Barang Dagangan (X1)

Tabel 1

Hasil Uji Validitas Variabel Barang Dagangan (X1)

\begin{tabular}{cccc}
\hline $\mathbf{X}$ & rhitung & rtabel & kesimpulan \\
\hline $\mathbf{X 1 . 1}$ & 0,768 & 0,196 & Valid \\
\hline $\mathbf{X 1 . 2}$ & 0,869 & 0,196 & Valid \\
\hline
\end{tabular}

$\begin{array}{llll}\text { X1.3 } & 0,778 & 0,196 & \text { Valid }\end{array}$

Sumber Data Primer Diolah (2019)

Tabel 1 menunjukan bahwa hasil rhitung > rtabel untuk setiap item pertanyaan tentang variabel barang dagangan. Maka dapat ditentukan bahwa item pertanyaan 1,2,dan 3 adalah valid.

Variabel Lokasi Toko (X2)

Tabel 2

Hasil Uji Validitas Lokasi Toko (X2)

\begin{tabular}{cccc} 
X & rhitung & rtabel & kesimpulan \\
\hline X2.1 & 0,845 & 0,196 & Valid \\
\hline X2.2 & 0,585 & 0,196 & Valid \\
\hline X2.3 & 0,744 & 0,196 & Valid \\
\hline X2.4 & 0,648 & 0,196 & Valid \\
\hline
\end{tabular}

Sumber Data Primer Diolah (2019)

Tabel 2 menunjukan bahwa hasiL rhitung > rtabel untuk setiap item pernyataan tentang variabel lokasi toko. Maka dapat ditentukan bahwa item pertanyaan $1,2,3$, dan 4 adalah valid.

Variabel Pelayanan Pegawai (X3)

Tabel 3

Hasil Uji Validitas Pelayanan Pegawai (X3)

\begin{tabular}{cccc}
\hline $\mathbf{X}$ & rhitung & rtabel & kesimpulan \\
\hline $\mathbf{X 3 . 1}$ & 0,738 & 0,196 & Valid \\
\hline $\mathbf{X 3 . 2}$ & 0,638 & 0,196 & Valid \\
\hline $\mathbf{X 3 . 3}$ & 0,797 & 0,196 & Valid \\
\hline
\end{tabular}

Sumber Data Primer Diolah (2019)

Tabel 3 menunjukan bahwa hasil rhitung > rtabel untuk setiap item pertanyaan tentang variabelpelayanan pegawai.Maka dapat ditentukan bahwa item pertanyaan 1,2,dan 3 adalah valid.

Variabel Harga (X4)

Tabel 4

Hasil Uji Validitas Harga (X4)

\begin{tabular}{cccc}
\hline $\mathbf{X}$ & rhitung & rtabel & kesimpulan \\
\hline $\mathbf{X 4 . 1}$ & 0,879 & 0,196 & Valid \\
\hline $\mathbf{X 4 . 2}$ & 0,712 & 0,196 & Valid \\
\hline $\mathbf{X 4 . 3}$ & 0,864 & 0,196 & Valid \\
\hline \multicolumn{4}{c}{ Sumber Data Primer Diolah $(2019)$}
\end{tabular}

Table 4 menunjukan bahwa hasil rhitung > rtabel untuk setiap item pertanyaan tentang variabel harga.Maka dapat ditentukan bahwa item pertanyaan 1,2, dan 3 adalah valid.

Variabel Keputusan Pembelian (Y)

Tabel 5 
Hasil Uji Validitas Keputusan Pembelian (Y)

\begin{tabular}{cccc}
\hline $\mathbf{X}$ & rhitung & rtabel & kesimpulan \\
\hline Y1.1 & 0,801 & 0,196 & Valid \\
\hline Y1.2 & 0,647 & 0,196 & Valid \\
\hline Y1.3 & 0,738 & 0,196 & Valid \\
\hline Y1.4 & 0,901 & 0,196 & Valid \\
\hline \multicolumn{4}{c}{ Sumber Data Primer Diolah $(2019)$}
\end{tabular}

Table 5 menunjukan bahwa hasiL rhitung > rtabel untuk setiap item pernyataan tentang variabel keputusan pembelian. Maka dapat ditentukan bahwa item pertanyaan 1,2,3, dan 4 adalah valid.

\section{Uji Reliabilitas}

Variabel Barang Dagangan (X1)

$$
\text { Tabel } 6
$$

Hasil Uji Reabilitas Barang Dagangan (X1)

\section{Reliability Statistics}

\begin{tabular}{|r|r|}
\hline $\begin{array}{c}\text { Cronbach's } \\
\text { Alpha }\end{array}$ & N of Items \\
\hline .829 & 4 \\
\hline
\end{tabular}

Sumber Data Primer Diolah (2019)

Hasil pengujian reliabilitas terhadap variabel Barang

Dagangan dengan Cronbach's Alpha terlihat pada

Tabel 6 menunjukan bahwa nilai Alpha > 0.6.oleh

karena itu dapat ditentukan bahwa instrument

penelitian ini adalah reliable

Variabel Lokasi Toko (X2)

\section{Tabel 7}

Hasil Uji Reliabitas Lokasi Toko (X2)

\section{Reliability Statistics}

\begin{tabular}{|r|r|}
\hline $\begin{array}{c}\text { Cronbach's } \\
\text { Alpha }\end{array}$ & N of Items \\
\hline .780 & 5 \\
\hline
\end{tabular}

Sumber Data Primer Diolah (2019)

Hasil pengujian reliabilitas terhadap variabelLokasi Toko dengan Cronbach's Alpha terlihat pada Tabel 7 menunjukan bahwa nilai Alpha > 0.6.oleh karena itu dapat ditentukan bahwa instrument penelitian ini adalah reliabel.

Variabel Pelayanan Pegawai (X3)

Tabel 8

Hasil Uji Reliabitas Pelayanan Pegawai (X3)

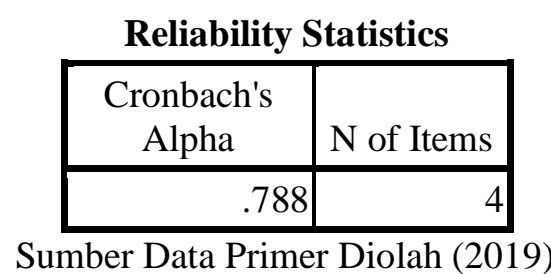

Hasil pengujian reliabilitas terhadap variabel Pelayanan Pegawai dengan Cronbach's Alpha terlihat pada Tabel 8 menunjukan bahwa nilai Alpha lebih besar dari 0.6.oleh karena itu dapat ditentukan bahwa instrumen penelitian ini adalah reliabel.

Variabel Harga (X4)

Tabel 9

Hasil Uji Reliabitas Harga (X3)

\section{Reliability Statistics}

\begin{tabular}{|r|r|}
\hline $\begin{array}{c}\text { Cronbach's } \\
\text { Alpha }\end{array}$ & N of Items \\
\hline .835 & 4 \\
\hline
\end{tabular}

Sumber Data Primer Diolah (2019)

Hasil pengujian reliabilitas terhadap variabel Harga dengan Cronbach's Alpha terlihat pada Tabel 9 menunjukan bahwa nilai Alpha lebih besar dari 0.6.oleh karena itu dapat ditentukan bahwa instrumen penelitian ini adalah reliabel.

Variabel Keputusan Pembelian (Y)

Tabel 10

Hasil Uji Reliabitas Keputusan Pembelian (Y)

\section{Reliability Statistics}

\begin{tabular}{|r|r|}
\hline $\begin{array}{c}\text { Cronbach's } \\
\text { Alpha }\end{array}$ & N of Items \\
\hline .808 & 5 \\
\hline
\end{tabular}

Sumber Data Primer Diolah

Hasil pengujian reliabilitas terhadap variabel Keputusan Pembelian dengan Cronbach's Alpha terlihat pada Tabel 10 menunjukan bahwa nilai Alpha lebih besar dari 0.6,oleh karena itu dapat ditentukan bahwa instrumen penelitian ini adalah reliabel.

\section{Hasil Uji Asumsi Klasik \\ Uji Normalitas}

Tabel 11

Hasil Uji Normalitas 


\begin{tabular}{ccc}
\hline Model & Signifikansi & Keputusan \\
\hline 1 & 0,075 & normal
\end{tabular}

Sumber : Data diolah peneliti (2019)

Tabel di atas menunjukkan hasil uji normalitas data sebesar 0,075 lebih besar dari 0,05 maka dapat disimpulkan bahwa data penelitian ini berdistribusi normal.

Uji Multikolinieritas

Tabel 12

Hasil Uji Multikolinieritas

\begin{tabular}{llcl}
\hline Variabel & Tolerance & VIF & Kesimpulan \\
\hline X1 & .438 & 2.283 & $\begin{array}{l}\text { Bebas } \\
\text { Multikolinieritas }\end{array}$ \\
\hline X2 & .319 & 3.133 & $\begin{array}{l}\text { Bebas } \\
\text { Multikolinieritas }\end{array}$ \\
\hline X3 & .384 & 2.607 & $\begin{array}{l}\text { Bebas } \\
\text { Multikolinieritas }\end{array}$ \\
\hline X4 & .332 & 3.008 & $\begin{array}{l}\text { Bebas } \\
\text { Multikolinieritas }\end{array}$ \\
\hline
\end{tabular}

Sumber : Data diolah peneliti (2019)

Berdasarkan hasil pengujian multikolinieritas pada tabel 12 di atas, dapat disimpulkan bahwa barang dagangan, lokasi toko, pelayanan pegawai, dan harga terhadap keputusan pembelian bebas dari multikolinieritas, karena batas tolerance value lebih besar dari 0,10 dan variance inflation factor (VIF) adalah lebih kecil dari 10.

Uji Heroskedastisitas

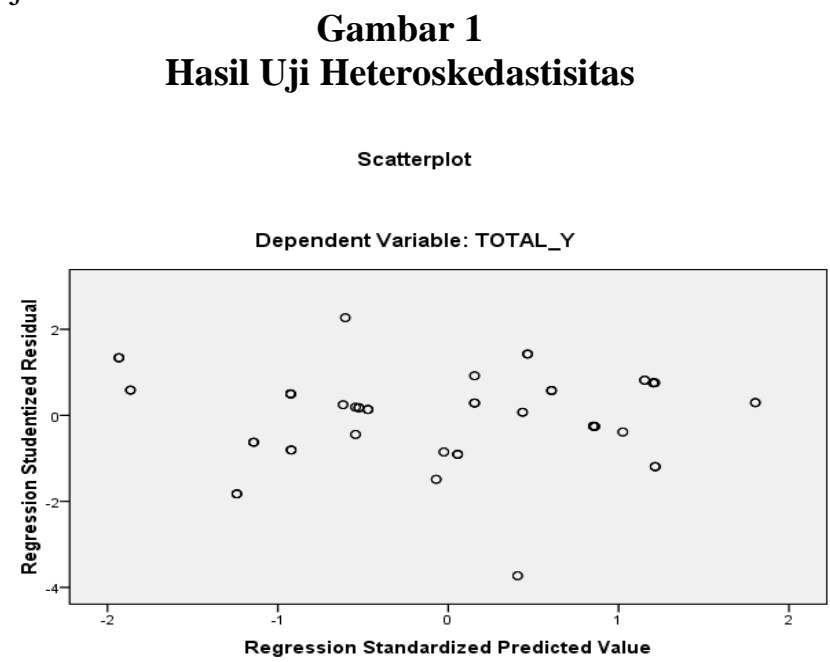

Sumber : Data diolah penulis (2019)

Pada gambar scatterplot diatas menunjukkan penyebaran titik-titik data sebagai berikut:
1) Titik-titik data menyebar di atas dan di bawah atau disekitar angka 0 .

2) Titik-titik data tidak mengumpul hanya di atas atau di bawah saja.

3) Penyebaran titik-titik data tidak boleh membentuk pola bergelombang melebar kemudian menyempit dan melebar kembali.

Maka dapat disimpulkan bahwa model regresi linear berganda terbebas dari asumsi klasik heteroskedastisitas dan layak digunakan dalam penelitian.

\section{Analisis Regresi Sederhana}

Tabel 13

Hasil Uji Regresi Berganda

\begin{tabular}{cc}
\hline Variabel & Koefisien Regresi \\
\hline TOTAL_X1 & 0,398 \\
TOTAL_X2 & 0,086 \\
TOTAL_X3 & 0,189 \\
TOTAL_X4 & 0,337 \\
\hline
\end{tabular}

Sumber : Data diolah penulis (2019)

Hasil perhitungan dalam persamaan regresi diperoleh 0,398 untuk koefisien barang dagangan, 0,086 untuk lokasi toko, 0,189 untuk pelayanan pegawai dan untuk harga sebesar 0,337. Berdasarkan hasil perhitungan tersebut, maka persamaan regresi dapat dirumuskan sebagai berikut:

$$
\mathrm{Y}=0,398 \mathrm{X} 1+0,086 \mathrm{X} 2+\mathbf{0 , 1 8 9 X 3}+\mathbf{0 , 3 3 7 X} 4+\varepsilon
$$

Keterangan :

\begin{tabular}{|c|c|}
\hline Y1 & $=$ Keputusan Pembelian \\
\hline $\mathrm{X} 1$ & $=$ Barang Dagangan \\
\hline $\mathrm{X} 2$ & $=$ Lokasi Toko \\
\hline $\mathrm{X} 3$ & $=$ Pelayanan Pegawai \\
\hline $\mathrm{X} 4$ & $=$ Harga \\
\hline$\varepsilon$ & $=$ erorr term \\
\hline
\end{tabular}

Berdasarkan persamaan diatas dapat dijelaskan pengertian sebagai berikut :

a. Barang Dagangan memiliki koefisien regresi sebesar 0,398 dan bertanda positif, sehingga dapat diartikan semakin baik barang dagangan yang dimiliki maka semakin tinggi keputusan pembelian konsumen. Hal ini mengandung arti bahwa apabila koefisien regresi variabel lainnya tetap, maka perubahan barang dagangan sebesar $1 \%$ akan menaikkan keputusan pembelian sebesar 0,398.

b. Lokasi Toko memiliki koefisien regresi sebesar 0,086 dan bertanda positif, sehingga dapat diartikan semakin pelayanan pegawai berkurang maka semakin tinggi keputusan pembelian konsumen. Hal ini mengandung arti bahwa apabila koefisien regresi 
variabel lainnya tetap, maka perubahan lokasi toko sebesar $1 \%$ akan menaikkan keputusan pembelian sebesar 0,086 .

c. Pelayanan Pegawai memiliki koefisien regresi sebesar 0,189 dan bertanda positif, sehingga dapat diartikan semakin baik pelayanan pegawai maka semakin tinggi keputusan pembelian konsumen. Hal ini mengandung arti bahwa apabila koefisien regresi variabel lainnya tetap, maka perubahan pelayanan pegawai sebesar $1 \%$ akan menaikkan keputusan pembelian sebesar 0,189 .

d. Harga memiliki koefisien regresi sebesar 0,337 dan bertanda positif, sehingga dapat diartikan semakin baik harga yang dimiliki semakin tinggi keputusan pembelian konsumen. Hal ini mengandung arti bahwa apabila koefisien regresi variabel lainnya tetap, maka perubahan harga sebesar $1 \%$ akan keputusan pembelian sebesar 0,337 .

\section{Pengujian Hipotesis}

Uji Signifikan Parsial (Uji Statistik t)

\section{Tabel 14}

Hasil Uji t

\begin{tabular}{ccrrl}
\hline variabel & $\mathbf{t}_{\text {hitung }}$ & $\mathbf{t}_{\text {tabel }}$ & sig & interpretasi \\
\hline $\mathrm{X} 1$ & 3.260 & 1,985 & .002 & H1 diterima \\
\hline $\mathrm{X} 2$ & .598 & 1,985 & .551 & H2 ditolak \\
\hline $\mathrm{X} 3$ & 1.450 & 1,985 & .150 & H3 ditolak \\
\hline $\mathrm{X} 4$ & 2.400 & 1,985 & .018 & H4 diterima
\end{tabular}

Sumber : Data diolah peneliti (2019)

Berdasarkan hasil dari uji t pada tabel 14 dapat diperoleh hasil sebagai berikut :

1) Hasil uji t, barang dagangan diperoleh $t_{\text {hitung }}$ sebesar 3,260 dan signifikansi sebesar 0,002. Nilai $\mathrm{t}_{\text {hitung }}$ lebih besar dari $\mathrm{t}_{\text {tabel }}$ dan signifikansi barang dagangan lebih kecil dari 0,05 dan nilai koefisien regresi 0,398, maka dapat disimpulkan bahwa $\mathrm{HO}$ ditolak dan $\mathrm{H} 1$ diterima. Barang dagangan memiliki pengaruh signifikan terhadap keputusan pembelian.

2) Hasil uji t, lokasi toko diperoleh $t_{\text {hitung }}$ sebesar 0,598 dan signifikansi sebesar 0,551. Nilai $t_{\text {hitung }}$ lokasi tokolebih kecil dari tabel dan signifikansi lokasi toko lebih besar dari 0,05, maka dapat disimpulkan bahwa $\mathrm{H} 0$ diterima dan $\mathrm{H} 2$ ditolak. Lokasi toko tidak berpengaruh secara signifikan terhadap keputusan pembelian.

3) Hasil uji $t$ pelayanan pegawai diperoleh $t_{\text {hitung }}$ sebesar 1,450 dan signifikansi sebesar 0,150. Nilai $t_{\text {hitung }}$ pelayanan pegawailebih kecil dari $t_{\text {tabel }}$ dan signifikansi promosi lebih besar dari 0,05 , maka dapat disimpulkan bahwa $\mathrm{H} 0$ diterima dan $\mathrm{H} 3$ ditolak. Pelayanan pegawai tidak berpengaruh secara signifikan terhadap keputusan pembelian.

4) Hasil uji t harga diperoleh $t_{\text {hitung }}$ sebesar 2,400 dan signifikansi sebesar 0,018. Nilai thitung lebih besar dari $t_{\text {tabel }}$ dan signifikansi harga lebih kecil dari 0,05, maka dapat disimpulkan bahwa H0 ditolak dan $\mathrm{H} 4$ diterima. Harga memiliki pengaruh secara signifikan terhadap keputusan pembelian.

\section{Uji Signifikansi Simultan (Uji Statistik F)}

Tabel 15

Hasil Uji F

\begin{tabular}{cccc}
\hline $\mathbf{F}_{\text {hitung }}$ & $\mathbf{F}_{\text {tabel }}$ & Signifikansi & Interpretasi \\
\hline 14.458 & 2,470 & $.000^{\mathrm{b}}$ & H5 diterima \\
\hline
\end{tabular}

Sumber : Data diolah peneliti (2019)

Berdasarkan tabel 15 hasil uji $\mathrm{F}$ di atas diperoleh $\mathrm{F}_{\text {hitung }}$ sebesar $14.458 \quad\left(F_{\text {hitung }} 14.458>F_{\text {tabel }} 2,470\right)$. Nilai probabilitas lebih kecil dari 0,05 (sig $\mathrm{F}_{\text {hitung }} 0,000<$ 0,05), maka dapat disimpulkan $\mathrm{H} 0$ ditolak yang berarti bahwa variabel barang dagangan, lokasi toko, pelayanan pegawai, dan harga secara bersama-sama berpengaruh terhadap keputusan pembelian.

Koefisien Determinasi

\section{Tabel 16 Hasil Koefisien Determinasi}

\begin{tabular}{cc}
\hline Model & Adjusted R. Square \\
\hline 1 & 0,352 \\
\hline Sumber : Data diolah peneliti (2019)
\end{tabular}

Berdasarkan tabel 16 di atas hasil Adjusted R. Square diperoleh nilai sebesar 0,352 . Hal ini menunjukkan bahwa hanya $35,2 \%$ variasi dari keputusan pembelian dapat dijelaskan oleh variabel barang dagangan, lokasi toko, pelayanan pegawai, dan harga. Sedangkan sisanya sebesar $64,8 \%$ dijelaskan oleh variabel lain yang tidak masuk dalam model penelitian.

\section{PEMBAHASAN}

Uji Signifikan Parsial (Uji Statistik t)

Berdasarkan hasil dari uji t dapat diperoleh hasil sebagai berikut :

Hasil uji $\mathrm{t}$ barang dagangan diperoleh $\mathrm{t}_{\text {hitung }}$ sebesar 3,260 dan signifikansi sebesar 0,002. Nilai $t_{\text {hitung }}$ lebih besar dari $t_{\text {tabel }}$ dan signifikansi barang dagangan lebih kecil dari 0,05 dan nilai koefisien regresi 0,398, maka dapat disimpulkan bahwa $\mathrm{H} 0$ 
ditolak dan $\mathrm{H} 1$ diterima. Hal ini berarti barang dagangan yang semakin baik dan semakin diminati konsumen maka akan meningkatkan keputusan pembelian.

Hasil uji t lokasi toko diperoleh $t_{\text {hitung }}$ sebesar 0,598 dan signifikansi sebesar 0,551. Nilai thitung hargalebih kecil dari tabel dan signifikansi harga lebih besar dari 0,05, maka dapat disimpulkan bahwa H0 diterima dan $\mathrm{H} 2$ ditolak. Hal ini berarti lokasi toko yang jauh ataupun dekat tidak mempengaruhi keputusan pembelian karena jika barang yang dijual berkualitas dengan harga yang lebih baik dibandingkan dengan toko lain maka akan menarik konsumen untuk tetap membeli.

Hasil uji t pelayanan pegawai diperoleh $t_{\text {hitung }}$ sebesar 1,450 dan signifikansi sebesar 0,150. Nilai $t_{\text {hitung }}$ pelayanan pegawailebih kecil dari $t_{\text {tabel }}$ dan signifikansi pelayanaan pegawai lebih besar dari 0,05 , maka dapat disimpulkan bahwa $\mathrm{H} 0$ diterima dan $\mathrm{H} 3$ ditolak. Hal ini berarti konsumen tidak mempedulikan pelayanan yang mereka terima tetapi mereka lebih tertarik dengan kualitas barang dan harga yang dimiliki toko tersebut.

Hasil uji t harga diperoleh $t_{\text {hitung }}$ sebesar 2,400 dan signifikansi sebesar 0,018 . Nilai thitung lebih besar dari $t_{\text {tabel }}$ dan signifikansi harga lebih kecil dari 0,05, maka dapat disimpulkan bahwa $\mathrm{H} 0$ ditolak dan $\mathrm{H} 4$ diterima. Hal ini berarti harga yang semakin baik akan membuat para konsumen tertarik untuk membeli karena kualitas yang dimiliki juga lebih baik.

\section{Uji Signifikansi Simultan (Uji Statistik F)}

Berdasarkan hasil uji $\mathrm{F}$ di atas diperoleh $\mathrm{F}_{\text {hitung }}$ sebesar 14.458 ( $\left.F_{\text {hitung }} 14.458>F_{\text {tabel }} 2,470\right)$. Nilai probabilitas lebih kecil dari 0,05 (sig $\mathrm{F}_{\text {hitung }} 0,000<$ $0,05)$, maka dapat disimpulkan $\mathrm{H} 0$ ditolak yang berarti bahwa variabel barang dagangan, lokasi toko, pelayanan pegawai, dan harga secara bersama-sama berpengaruh terhadap keputusan pembelian.

\section{Uji Koefisien Determinasi}

Berdasarkan hasil uji Adjusted R. Square diperoleh nilai sebesar 0,352 . Hal ini menunjukkan bahwa hanya $35,2 \%$ variasi dari keputusan pembelian dapat dijelaskan oleh variabel barang dagangan, lokasi toko, pelayanan pegawai, dan harga. Sedangkan sisanya sebesar $64,8 \%$ dijelaskan oleh variabel lain yang tidak masuk dalam model penelitian.

\section{KESIMPULAN DAN SARAN}

1. Variabel Barang Dagangan berpengaruh signifikan dan positif terhadap keputusan pembelian. Hal ini berarti barang dagangan yang semakin baik dan semakin diminati konsumen maka akan meningkatkan keputusan pembelian.

2. Variabel lokasi toko tidak berpengaruh terhadap keputusan pembelian karena jika barang yang dijual berkualitas dengan harga yang lebih baik dibandingkan dengan toko lain maka akan menarik konsumen untuk tetap membeli.

3. Variabel pelayanan pegawai tidak berpengaruh terhadap keputusan pembelian. Hal ini karena konsumen tidak mempedulikan pelayanan yang mereka terima tetapi mereka lebih tertarik dengan kualitas barang dan harga yang dimiliki toko tersebut.

4. Variabel harga berpengaruh signifikan terhadap keputusan pembelian. Hal ini berarti harga yang semakin baik akan membuat para konsumen tertarik untuk membeli karena kualitas yang dimiliki juga lebih baik.

5. Variabel barang dagangan, lokasi toko, pelayanan pelanggan, dan harga berpengaruh secara bersamasama terhadap keputusan pembelian.

\section{Keterbatasan Penelitian}

Keterbatasan dalam penelitian ini adalah hasil koefisien determinasi yang masih kecil yaitu sebesar 35,2\% membuktikan bahwa model regresi yang diambil oleh peneliti masih jauh dari sempurna dan bisa dikatakan kurang bagus.

\section{Saran}

Berdasarkan hasil dari penelitian ini disarankan sebaiknya Toko Bintang Aquarium Solo perlu :

1. Disarankan kepada pemilik Toko Bintang Aquarium Solo lebih aktif lagi dalam mempromosikan baik lewat brosur maupun sosmed.

2. Disarankan untuk peneliti selanjutnya untuk menambah variabel penelitian agar hasilnya lebih akurat dan lebih baik lagi.

\section{DAFTAR PUSTAKA}

[1] Christian Hadi Wijaya (2012) Pengaruh Store Image, Store Atmospherics, dan Store Theatrics Terhadap Purchase Intention pada The Body Shop Galaxy Mall Surabaya, Skripsi tidak 
dipublikasikan, Surabaya: Fakultas Manajemen Bisnis Universitas Katolik Widya Mandala.

[2] Ferdinand, Augusty. 2006. Metode Penelitian Manajemen. Edisi 2. BP. Universitas Diponigoro,

Makassar.

[3] Ferdinand, Augusty, 2006, Structural Equation Modeling Dalam Penelitian Manajemen: Aplikasi Model-model Rumit Dalam Penelitian Untuk Tesis Magister dan Disertasi Doktor, Edisi 4, Badan Penerbit Universitas Diponegoro, Semarang.

[4] Gede Wahyu Maharta, Made Any, Anjuman Zukhri (2017) Pengaruh Store mage Terhadap Keputusan Pembelian Konsumen Pada Krisna 5 Singaraja Ejournal pendidikan ekonomi vol 10 no 2 tahun 2017

[5] Ghozali, I. 2009. Aplikasi Analisis Multivariate Dengan Program SPSS. Semarang: Badan Penerbit Universitas Diponegoro.

[6] Kevin Lane, 2013. Manajemen Pemasaran, Jilid 1. Edisi 13.Erlangga.

[7] Kotler, Philip. 2007. Manajemen Pemasaran (judul asli: Marketing Management), edisi kedua belas, jilid 2. Penerjemah Benyamin Molan. Jakarta:PT Indeks.

[8] Kotler, P., Keller, K.L., 2008. Marketing Management, 13th ed. PrenticeHallInternational, Inc., NJ.

[9] Kotler, Philip \& Gary Amstrong, 2012.Principle of marketing. Upper Sadle And Keller,

[10] Mursyid, M. 2008. Manajemen Pemasaran. Cetakan Kelima. Jakarta : Binarupa Aksara.

[11] Nuryudiono, Achmad Fauzi, Imam Suyadi (2016) Pengaruh Store Image Terhadap Pembentukan Private Brand Image pada Giant Hypermarket Gayana Kota Malang Journal Administrasi Bisnis Gabungan Vol 32 No 1 Maret 2016 hal 9-17

[12] Rosa Lemana dan Juwardi (2017) Pengaruh Kelengkapan Produk dan Penetapan Harga Terhadap Keputusan Pembelian Konsumen (Studi Kasus Pada Toko H.Uding Asaek, Tanggerang)Jurnal Pemasaran Kompetitif Vol 1 No 1 Oktober 2017 Hal 1-19

[13] Rao, Purba (1996), Measuring Consumer Perceptions Through Factor Analysis. The Asian Manager, February-March, pp.28-32
[14] Simamora, Bilson. (2002). Aura Merek (Tujuh Langkah Membangun Merek Yang Kuat). Jakarta: PT. Gramedia Pustaka Utama.

[15] Sugiyono,2010. Metode Penelitian Kuantitatif, Kualitatif, dan $R \& D$. Bandung: Alfabeta

[16] Tomy Soebagyo dan Hartono Subagio (2014) Analisa Pengaruh Store Image Terhadap Purchase Intention di Toserba "Ramai" NgawiJurnal Manajamen Pemasaran Vol 1 No 2 (2014) Hal 1-9

[17] Utami, Christina Whidya. (2008). Manajemen Barang Dagangan Dalam Bisnis Ritel.Malang: Bayumedia Publishing 